\title{
PENGEMBANGAN BUKU SUPLEMEN 3D AUGMENTED REALITY SEBAGAI BAHAN BELAJAR TEMATIK TEMA LINGKUNGAN TENTANG PERKEMBANGBIAKAN HEWAN UNTUK SISWA KELAS III SD
}

\author{
Irfanda Jamhari', Susilaningsih ${ }^{2}$, Saida Ulfa ${ }^{3}$ \\ Universitas Negeri Malang \\ E-mail: pandaextrem@gmail.com
}

\begin{abstract}
ABSTRAK
Kegiatan belajar merupakan suatu aktifitas yang tidak akan terpisahkanselama manusia hidup. Dan seiring perkembangan zaman,kemajuanteknologi terus melesat canggih sehingga dalam proses pembelajaran juga hendaknya memanfaatkan kemajuan teknologi tersebut.Tujuan penelitian ini yaitu menghasilkan buku suplemen dengan teknologi augmented reality pada mata pelajaran tematik tema lingkungan tentang perkembangbiakan hewan yang tervalidasi dalam kegiatan pembelajaran tematik SD kelas III. Pengembangan ini telah melalui tahap pengumpulan informasi,prencanaan,pengembangan produk,uji coba lapangan tahap awal,revisi,uji coba lapangan dan revisi produk akhirselaras dengan model pengembanganBorg and Gall (Sugiyono,2012:297) yang sudah di modifikasi sesuai kebutuhan peneliti. Validasi produk dilakukan terhadap ahli media dan ahli materi. Sasaran uji coba media ini adalah siswa kelas III SDN 01 Jedong Malang. Pengembangan ini menghasilkan kriteria valid dengan perolehan total persentase ahli media 96,42\%, ahli materi 84,2\%, dan uji coba lapangan 83,43\%.Sehingga buku suplemen dengan teknologi augmented reality ini dinyatakan valid dan layak untuk digunakan di lapangan
\end{abstract}

Kata kunci: Buku Suplemen, Augmented Reality, Perkembangbiakan Hewan.

\section{PENDAHULUAN}

Kegiatan belajar adalah suatu aktifitas yang tidak dapat terpisahkan dalam kehidupan manusia. Menurut Reber (Sugihartono dkk, 2007) menyatakan belajar dalam dua pengertian. Pertama, belajar adalah proses memperoleh pengetahuan dan kedua, belajar adalah perubahan kemampuan berkreasi yang relatif sebagai hasil penguatan dari latihan. Belajar bisa diperoleh dengan berbagai cara,salah satunya yaitu melalui Pendidikan. Pendidikan adalah kunci dari perkembangan yang berkualitaskarena dengan pendidikan manusia dapat mewujudkan semua potensi dirinya baik sebagai dirinya sendiri maupun dalam lingkungan sekitar. Menurut Suardi (2012) "tujuan pendidikan merupakan seperangkat hasil pendidikan yang dicapai oleh peserta didik setelah diselenggarakan kegiatan pendidikan". Maka, dapat diartikan bahwa dengan pendidikan yang baik akan mampu mencapai tujuan pendidikan yang baik pula pada siswa. Dalam proses pembelajaran itu sendiri dibutuhkan perangkat - perangkat penunjang seperti sumber belajar yang dapat mempermudah dan membantu guru dalam menyampaikan pesan atau informasi kepada peserta didik. Sumber belajar ini salah satunya yaitu berupa bahan cetak. Sumber belajar berupa bahan cetak berupa buku merupakan alat paling konvensional digunakan oleh guru dalam menyampaikan materi.Dalam Permendikbud Nomor 8 Tahun 2016 tentang Buku yang Digunakan oleh Satuan Pendidikan telah ditetapkan antara lain bahwa "Buku teks pelajaran merupakan perangkat operasional utama atas pelaksanaan kurikulum dan buku non teks pelajaran merupakan saran pendukung untuk memfasilitasi pelaksanaan ,penilaian, dan pengembangan pembelajaran untuk peserta didik dan pendidik sehingga diharuskan memenuhi kriteria buku yang layak digunakan dalam satuan pendidikan". Sehingga dari pernyataan tersebut,penggunaan buku teks dalam proses pembelajaran di sekolah merupakan hal yang diwajibkan oleh pemerintah dalam penyelenggaraan pendidikan di Indonesia. Tetapi 
penggunaan buku teks yang hanya mengandalkan teks dan gambar saja dalam proses pembelajaran dirasa masih kurang untuk memfasilitasi kegiatan belajar siswa. Hal ini yang layak mendapat perhatian lebih dari berbagai pihak. Pembelajaran tematik kelas III SD tema satu, perkembangbiakan hewan adalah kemampuan untuk memperbanyak atau mempertahankan jenisnya. Setiap makhluk hidup berusaha melestarikan jenisnya dari kepunahan. Maka dari itu, setiap makhluk hidup memiliki kemampuan untuk berkembang biak. Berkembang biak adalah cara menghasilkan keturunan atau anak. Tujuan pembelajaran dalam perkembangbiakan pada hewan ini adalah siswa dapat mengidentifikasi dan mengelompokan cara perkembangbiakan hewan dengan benar. Materi perkembangbiakan hewan pada kelas III SD membutuhkan visualisasi yang lebih dari sekedar teks dan gambar saja. Menurut Ibda (2015) Anak dalam rentang usia 6 12 tahun berada dalam tahap perkebangan kognitif operasional konkrit dimana anak sudah cukup matang untuk menggunakan pemikiran logika atau operasi,tetapi hanya untuk objek fisik yang ada saat ini. Sehingga dalam materi tersebut membutuhkan media yang dapat menunjukan penjelasan yang lebih konkrit dan wujud asli dari hewan - hewan dalam pengelompokan tersebut.

Berdasarkan wawancara non formal yang dilakukan di SDN 01 Jedong Malang, guru merasa kurang dapat memberikan pembelajaran yang menarik dan bermakna kepada siswa. Pembelajaran yang hanya menggunakan buku terkesan kurang menarik. Hal ini mempengaruhi pemahaman siswa mengenai macam macam hewan yang beranak dan bertelur. Menurut guru, penjelasan di buku kurang mampu menvisualisasikan macam macam hewan sesuai klasifikasinya secara nyata.

Berdasarkan pemaparan diatas,buku suplemen sebagai buku tambahan dari buku teksdirasa perlu dikembangkan guna mengatasi masalah yang telah dijelaskan. Buku suplemen ini nantinya akan berfungsi untuk memperdalam pemahaman anak tentang macam - macam hewan beranak dan bertelur menggunakan teknologi augmented reality sehingga buku suplemen mampu memberikan kebutuhan visual yang sangat kuat untuk siswa dalam memahami materi tema lingkungan tentang perkembangbiakan hewan.

Penggunaan teknologi sebagai inovasi dalam pembelajaran dirasa sangat perlu untuk dikembangkan lebih dalam lagi. Sehingga penggunaan teknologi augmented realityadalah salah satu inovasi yang dapat digunakan peneliti dalam mengembangkan buku suplemen. Untuk menggunakan teknologi ini,setidaknya dibutuhkan media utama sebagai perantara antara realitas maya dengan lingkungan nyata. Perantara tersebut berupa smartphone.Smartphone di era ini merupakan hal yang paling mudah ditemukan disekitar kita. Sehingga penggunaan teknologi augmented reality pada buku suplemen dapat berlanjut untuk dikembangkan.

Hal inilah yang melatarbelakangi pengembangan buku suplemen dengan teknologi augmented reality,dimana teknologi ini dapat membantu guru untuk memberikan visualisasi yang lebih nyata dengan inovasi yang menarik dalam menyampaikan materi tentang perkembangbiakan hewan. Siswa juga dapat menggunakan buku suplemen ini sebagai bahan belajar individu dirumah,dengan atau tanpa didampingi oleh orang tua. Buku suplemen Menurut Kurniasari dalam (Rizki,Mira 2016) adalah buku yang berfungsi untuk mendampingi atau melengkapi buku utama. Sehingga buku ini nantinya akan berfungsi sebagai tambahan untuk buku teks atau buku utama. Sehingga guru dapat menggunakan buku suplemen ini kapanpun jika diperlukan suatu pemahaman yang lebih dalam lagi atas materi yang sedang dijelaskan begitu juga dengan siswa. 
Penjelasan diatas ini yang melatarbelakangi penelitian pengembangan ini makapeneliti melakukan penulisan skripsi dengan judul "Pengembangan Buku Suplemen 3d Augmented Reality Sebagai Bahan Belajar Tematik Tema Lingkungan Tentang Perkembangbiakan Hewan Untuk Siswa Kelas III SD".

Berdasarkan judul skripsi yang ditentukan oleh pengembang, adapun tujuan yang ingin dicapai dalam penelitian pengembangan buku suplemen dengan teknologi augmented reality adalah mengembangkan media pembelajaran berupa bahan cetak buku suplemenyang dilengkapi teknologi augmented realityyang valid untuk digunakan dalam proses pembelajaran serta sesuai dengan kebutuhan pebelajar.

\section{METODE PENELITIAN}

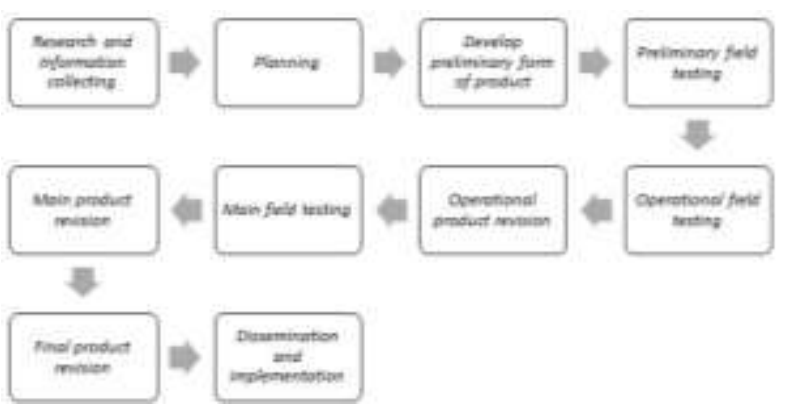

Bagan Model Penelitian dan Pengembangan Borg anda Garl (2003)

Penelitian pengembangan ini menggunakan model penelitian dan pengembangan yang diadaptasi dari model pengembangan oleh Borg \& Gall (2003). Model ini digunakan karena sesuai untuk diterapkan pada penelitian pengembangan buku suplemen dengan teknologi augmented realitydengan tahap-tahap yang telah dimodifikasimeliputi tujuh kegiatan yaitu : (1) Research and information collecting; (2) planning; (3) Develop preliminary form of product; (4) Preliminary field testing; (5) Main product revision; (6) Preliminary Field Testing; (7) Operational Product Revision

1. Tahap mengumpulkan informasi merupakan langkah awal penelitianguna mencari potensi dan masalah yang dialami serta solusiyang dibutuhkan oleh siswa kelas III SDN Jedong 01 Malang. Langkah awal yang dilakukan oleh peneliti untuk menentukan potensi dan masalah dalam melakukan penelitian pengembangan ini yaitu mengkaji teori yang relevan dengan penelitian dan melakukan kegiatan wawancara singkat dengan kepala sekolah, guru ,dan siswa di SD Negeri Jedong 01 Kota Malang. Dan ditemukan bahwa guru mempunyai permasalahan dalam menjelaskan Tema 1 Perkembangbiakan Hewan karena gambar yang terdapat pada buku paket dirasa masih kurang menggambarkan wujud - wujud hewan dalan setiap klasifikasinya dan kurang memperkuat penyampaian guru terhadap materi yang disajikan.

2. Tahap kedua yaitu perencanaan. Perencanaan dalam pembuatan buku suplemen Augmented Reality ini sangat penting untuk dilakukan. Dalam tahap ini dilakukan penentuan tujuan dari pengembangan,serta merencanakan proses pengembangan dan uji coba. Tujuan dalam pengembangan buku suplemen Augmented Reality ini adalah untuk membantu memudahkan guru dalam menyampaikan materi perkembangbiakan hewan dalam buku tematik tema 1 tentang lingkungan dan memberikan bahan belajar yang lebih konkrit dan bermakna untuk siswa. Adapun rencana proses pengembangan adalah pertama membuat rancangan desain buku suplemen. Tahap kedua mempersiapkan perangkat lunak (software) yang akan digunakan untuk mengembangkan program dari aplikasi Augmented Reality. Ketiga yaitu menyusun dan mengolah semua bahan - bahan yang tersedia sehingga menjadi sebuah buku suplemen yang dilengkapi dengan $3 D$ Augmented Reality. Terakhir adalah melakukan uji coba dengan dua tahap,yaitu uji coba pada ahli dan uji coba lapangan.

3. Tahap Ketiga yaitu tahap pengembangan produk. Pada Tahap ini, Peneliti membuat desain produk yang akan dikembangkan berupa buku suplemen $3 D$ 
Augmented Reality. Sebelum memasuki tahap pembuatan buku suplemen $3 D$ Augmented Reality, dibutuhkan suatu rancangan sebagai rujukan bagi pengembang agar tahap pengembangan tidak melenceng dengan apa yang direncanakan. Proses desain pengembangan buku suplemen $3 D$ Augmented Reality meliputi dua aspek desain, yaitu poses desain instruksional dan aspek isi pengajaran yang akan diberikan.

4. Tahap keempat yaitu uji coba lapangan awal Langkah ini merupakan uji coba produk secara terbatas yang hanya melibatkan ahli materi dan ahli media untuk proses validasi. Melakukan validasi desain dengan melibatkan para ahli yaitu ahli media dan ahli materi untuk memperbaiki dan menyempurnakan desain buku suplemen 3D Augmented Reality yang dikembangkan. Validasi ahli menggunakan teknik penyebaran angket.

5. Tahap kelima yaitu revisi desain Setelah melakukan validasi menurut para ahli, peneliti akan melakukan perbaikan jika ada kekurangan pada produk yang dikembangkan. Revisi ini diperoleh menurut masukan dari ahli media maupun ahli materi.Setelah melakukan revisi desain produk, peneliti akan memasukkan file aplikasi android 3D Augmented Reality ini ke dalam CD dan di kemas beserta buku suplemen agar mudah dalam penggunaan dan penyimpananya. Kemudian peneliti akan melakukan ujicoba di dalam pembelajaran dikelas untuk mengetahui kelayakan buku suplemen 3D Augmented Reality yang dikembangkan ini. 6. Tahap keenam yaitu ujicoba lapangan. Setelah revisi dilakukan maka langkah selanjutnyayaitu melakukan uji coba pada siswa SDN 01 Jedong untuk mengetahui tingkat kevalidan dari produk ini. Validasi produk pada uji coba lapangan ini menggunakan teknik penyebaran angket. Uji coba lapangan akan dilakukan pada 25 siswa kelas III SDN 01 Jedong,Malang.
7. Tahap ketujuh yaitu revisi dan produk akhir Dari hasil uji coba produk, peneliti akan melakukan perbaikan menurut saransiswa dan guru jika ada kekurangan pada produk buku suplemen 3D Augmented Realityyang dikembangkan ini. Saran dan komentar diperoleh dari angket yang diberikan kepada pengguna.Pengembangan buku suplemen 3D Augmented Reality ini akan dimasukkan ke dalam kemasan beserta CD yang berisi aplikasi dan akan dikemas agar mudah penggunaan dan penyimpananya. kemasan akan didesain menarik jika produk akhir telah dinyatakan layak digunakan.

Penelitian ini menggunakan instrumen yang berupa angket untuk menguji validitas media yang dilakukan. Proses pengumpulan data dilakukan oleh pengembang dengan langsung melakukan penelitian ke lapangan.

Dalam mengolah data keseluruhan, menggunakan rumus dari Arikunto (2010) sebagai berikut:

$\mathrm{P}=\frac{\sum \mathrm{X}}{\sum \mathrm{Xi}_{\mathrm{i}}} \times 100 \%$

Keterangan rumus:

$\mathrm{P} \quad=$ Persentase

$\sum \mathrm{X}=$ Skor responden dalam satu item

$\sum \mathrm{Xi}=$ Jumlah skor ideal dalam satu item $100 \%=$ Konstanta

Hasil dari pengelolaan data diatas, akan dilihat tingkat validitasnya dengan kriteria sebagai berikut.

\begin{tabular}{ll}
\hline Persentase & Ekuivalen \\
\hline $80 \%-100 \%$ & Valid dan layak \\
$60 \%-79 \%$ & $\begin{array}{l}\text { Cukup valid dan cukup } \\
\text { layak }\end{array}$ \\
$50 \%-59 \%$ & $\begin{array}{l}\text { Kurang valid dan kurang } \\
\text { layak }\end{array}$ \\
& $\begin{array}{l}\text { Tidak valid dan tidak } \\
\text { layak }\end{array}$ \\
\hline
\end{tabular}




\section{HASIL DAN PEMBAHASAN}

Validasi media dilakukan pada ahli media dan ahli materi. Untuk uji coba lapangan,peneliti langsung mendatangi SDN 01 Jedong untuk melakukan validasi.Validasi ini dilakukan guna mengukur tingkat validitas buku suplemenyang sudah dikembangkan.

Data validasi ahli media didapat dari 1 ahli media pembelajaran. Data validasi ahli materi didapat dari 1 guru sekaligus kepala SDN 01 Jedong. Data uji coba lapangan diambil dari 25 siswa kelas III SDN 01 Jedong

Hasil analisis data ahli media, terdapat 12 pertanyaan termasuk dalam kategori valid dan terdapat 2 pertanyaan termasuk dalam kategori cukup valid. Secara keseluruhan diperoleh hasil $96.42 \%$ maka berdasarkan kriteria yang ditentukan dapat dijelaskan bahwa buku suplemen $3 D$ Augmented Reality untuk mata pelajaran tematik tema lingkungan tentang perkembangbiakan hewan kelas III SDN 01 Jedong memenuhi kriteria valid dan layak digunakan dalam pembelajaran.

Hasil analisis data ahli materi, terdapat 8 pertanyaan termasuk dalam kategori valid,10 pertanyaan termasuk dalam kategori cukup valid dan 1 pertanyaan termasuk dalam kategori kurang valid. Secara keseluruhan diperoleh hasil 84,2\% maka berdasarkan kriteria yang ditentukan dapat dijelaskan bahwa buku suplemen $3 D$ Augmented Reality untuk mata pelajaran tematik tema lingkungan tentang perkembangbiakan hewan kelas III SDN 01 Jedong memenuhi kriteria valid dan layak digunakan dalam pembelajaran.

Hasil uji coba lapangan secara keseluruhan diperoleh hasil 83,43\% maka berdasarkan kriteria yang ditentukan dapat dijelaskan bahwa buku suplemen $3 D$ Augmented Reality untuk mata pelajaran tematik tema lingkungan tentang perkembangbiakan hewan kelas III SDN 01 Jedong memenuhi kriteria valid dan layak digunakan dalam pembelajaran. Hal ini menunjukan bahwa buku suplemen dengan tekologi augmented reality ini memenuhi kebutuhan guru dan siswa akan suatu bahan belajar yang inovatif dan menyenangkan bagi siswa. Buku suplemen ini lebih menekankan untuk memenuhi kebutuhan belajar secara visual dimana materi perkembangbiakan hewan pada kelas III SD membutuhkan kegiatan eksplorasi yang konkrit seperti Menurut Ibda (2015) Anak dalam rentang usia $6-12$ tahun berada dalam tahap perkebangan kognitif operasional konkrit dimana anak sudah cukup matang untuk menggunakan pemikiran logika atau operasi,tetapi terbataspada objek fisik yang ada saat ini.Untuk teknologi augmented reality sendiri juga memiliki kompatibilitasterhadap banyak media selain buku suplemen. Seperti beberapa penelitian seperti Ulfa Rohmah (2012) dalam penelitiannya yang berjudul "Aplikasi Augmented Reality Tata Surya (Semua Planet Mengelilingi Matahari) Menggunakan Mobile Android" menunjukan hasil penelitian sebesar $83,47 \%$ untuk nilai keseluruhan dan sudah dapat dikatakan sangat baik. Sedangkan untuk aspek tampilan didapatkan presentase 79,17\%, aspek aplikasi didapatkan presentase $84,86 \%$, aspek penggunaan didapatkan presentase $85 \%$ dan dari ketiga aspek tersebut aplikasi ini sudah dikatakan sangat baik. Dari kesimpulan yang diambil melalui kuesioner, diketahui model objek 3D yang dibuat dapat terealisasikan sesuai dengan objek-objek dalam tata surya, sehingga dapat memberikan informasi tentang arah rotasi dan revolusi tiap-tiap planet.Hasil dari penelitian Iwan Setya Nugraha (2014) yang berjudul "Pemanfaatan Augmented Reality Untuk Pembelajaran Pengenalan Alat Musik Piano" menunjukan bahwa teknologi $3 d$ augmented reality dapat dimanfaatkan untuk berbagai macam pembelajaran salah satunya yaitu pembelajaran musik. 


\section{KESIMPULAN}

Buku suplemen sangat dibutuhkan untuk mempermudah siswa dalam memahami materi mengenai perkembangbiakan hewan.Sejalan dengan tujuan pengembangan dalam penelitian ini, buku suplemen memenuhi kriteria valid. Artinya, buku suplemen ini sudah layak digunakan pada kegiatan pembelajaran.Buku

suplemendikembangkan berdasarkan tujuan pembelajaran yang ingin dicapai. Buku suplemen dengan teknologi augmented realitydifungsikan sebagai suplemen (tambahan) dalam kegiatan pembelajaran.

Media ini dapat dimanfaatkan didalam kegiatan pembelajaran di kelas maupun secara mandiri. Kelebihan dari buku suplemenini dibandingkan dengan pengembangan media sebelumnya adalah tidak membutuhkan penyimpanan data yang besar pada smartphone. Dan dengan teknologi augmented reality, buku ini dapat memberikan kebutuhan akan kegiatan belajar yang lebih konkrit dan menyenangkan bagi siswa.

Untuk meningkatkan manfaat buku suplemen yang dikembangkan dalam kegiatan pembelajaran dikelas maupun individu, terdapat beberapa saran antara lain. Bagi GuruKetika buku suplemen beserta aplikasi digunakan pada kegiatan pembelajaran di kelas, guru berperan sebagai pengguna yang memberikan contoh dan menunjukan fungsi dari aplikasi pada siswa dalam menggunakan buku suplemen.

Ketika kegiatan pembelajaran selesai, guru dapat mengevaluasi melalui tanya jawab terhadap siswa.Bagi siswa yang dirumahnya memiliki smartphone,buku suplemen ini dapat digunakan dengan atau tanpa didampingi oleh orang tua. Tergantung pemahaman siswa tentang bagaimana menggunakan smartphone. Sebelum mulai menggunakan buku suplemen,hendaknya siswa membaca petunjuk penggunaan yang tertera pada halaman depan buku suplemen. Sehingga tidak terjadi kesulitan dalam penggunaan buku suplemen dengan aplikasi Augmented Reality

\section{DAFTAR PUSTAKA}

Borg, Walter R., Gall,Joyce Meredith Damien. 2003. Educational Research: An Introduction (7 $7^{\text {th }}$ Edition), New York:longman.

Sugihartono,dkk (2007) Psikologi Pendidikan, Yogyakarta : UNY Press.

Arikunto,S.2010. Prosedur Penelitian : Suatu Pendekatan Praktek (Edisi Revisi III). Jakarta: PT. Rineka Cipta.

Rohmah, U. (2012). Aplikasi Augmented Reality Tata Surya (Semua Planet Mengelilingi Matahari) Menggunakan Mobile Android.

Sugiyono. 2012. Metode Penelitian Kuantitatif, Kualitatif, dan R\&D. Penerbit CV. Alfabeta:Bandung.

Kurniasari, D. A. (2014). Pengembangan Buku Suplemen IPA Terpadu dengan Tema Pendengaran Kelas VIII. Unnes Science Education Journal 3 (2), 463.

Nugraha, I. S., Satoto, K. I., \& Martono, K. T. (2014). Pemanfaatan Augmented Reality untuk pembelajaran pengenalan alat musik piano. Jurnal Teknologi dan Sistem Komputer, 2(1), 62-70.

Ibda, Fatimah 2015. "Perkembangan Kognitif: Teori Jean Piaget." Intelektualita 3.1

Permendikbud Nomor 8 Tahun 2016 tentang Buku yang Digunakan oleh Satuan Pendidikan. 